\title{
The Role of Entrepreneurial Orientation in Achieving Organization Performance through Business Model Innovation And Strategic Collaboration
}

(Study of Entrepreneurship on Hospital Organizations in Indonesia)

\author{
Sandra Dewi ${ }^{1 *}$, Rhenald Kasali ${ }^{1}$, Tengku Ezni Balqiah ${ }^{1}$, Anton Wachidin Widjaja ${ }^{1}$ \\ ${ }^{1}$ Faculty of Economics and Business, Universitas Indonesia \\ Email: sandramochtar@yahoo.com
}

\begin{abstract}
External environment faced by the firms today shows the uncertainty due to the disruptive change that occurs in all aspects. Impacts of the phenomenon of disruptive innovation, which upset the balance of the market, require all companies to renew themselves in order to maintain their positions in the competition. To that end, many researchers mentioned the importance of strategic management with entrepreneurial approach in the process of formulation and implementation of corporate strategy in the era of the 21 st century. This paper intended to represent the role of entrepreneurial orientation in creating superior and sustainable organizational performance, through business model innovation and collaborative strategic relationship, as inimitable intangible. This study uses hospital industry in Indonesia as the research context which currently faces disruptive change at the time of policy reformation regarding hospital payment system, and denoted the urgent need for entrepreneurial strategies to mitigate them. This conceptual paper is a preliminary steps prior to the empirical research, which expected to contribute to academics, researchers, and all of hospital stakeholders in deepening the understanding on hospital strategy - that should simultaneously consider business ethics, and also ensure the preservation of the relationship in the stakeholder networks with conflicting interests.
\end{abstract}

Keywords: Entrepreneurial orientation, business model innovation, stakeholder network capability, strategic collaboration, hospital industry

\section{Introduction}

In the era of the 21 st century today, all firms facee severe challenges from the uncertainty of the environment, due to the condition of changing the speed of reaction of the competition, so the researchers suggested a change in the pattern of competitive dynamics (Chen \& Miller, 2015). One source of uncertainty drawing the attention of researchers and entrepreneurs is the emergence of small-medium- companies as the actors of disruptive innovation with its innovative action which is found in many types of industries. Those companies are able to 
explore new business opportunities (Christensen \& Raynor, 2003; Christensen et al., 2015), to raise concerns for the managers of large and established companies thatare not capable to respond to these challenges (Christensen \& Overdorf, 2000).

As a result, a strategy that previously had brought success for the company, has now changed, and no longer shown the same results. So the key to the success of companies requires a change of the strategic orientation of the firm which formed by entrepreneurial dimensions (Covin, 1991; Kuratko et al., 2015), demonstrated through a flexible attitude, creative, and innovative, ongoing and encouraging reform (Ireland et al., 2003). Entrepreneurial-oriented perspective was considered as the most appropriate means to deal with an uncertain environment, due to the proactive characteristics that tend to innovate continuously, while other companies do not realize to have to do it (Covin \& Lumpkin, 2011).

Entrepreneurship in the health care organization is considered important to be observed because of the challenges of change in the management of the organization which was used to be a non-profit public organization, is now largely controlled by private and for profit companies, which is more oriented towards entrepreneurship (Maier et al., 2014). Implementation of entrepreneurship related to the innovation in the context of the health care industry, especially hospital industry sector has not been widely known. There is even a rejection of the innovation of several parties involved in the health care industry, including physicians (Herzlinger, 2014), whereas innovation is a key element of entrepreneurial principles (Covin, 1991 ). But now it is recognized to be the urgent need to use an entrepreneurial mindset in improving the health care system, which is considered a mistake in the competition so that the need for policy reforms related to the industry, which is now proceeding transition (Porter \& Tiesberg 2004; Porter \& Lee, 2013, Christensen et al., 2009). It still needs a lot of empirical evidence in implementing the concept entrepreneurship within a hospital organization (Rauch, 2015).

The change in regulatory related to hospital payment system in Indonesia since 2014, and the encouragement of digital innovation in the service of the hospital aretwo factors urging hospitals to renew its business model. These changes will make the existing business model becomes no longer able to maintain continuity of profit formula that includes models to generate revenue, cost structure, profit margins and speed the flow of resources to produce a target volume (Johnson et al., 2008). Therefore, it takes the form of business model innovation which will be associated with organizational changes and expansion of market segments (Hwang \& Christensen, 2008). Associated with entrepreneurial orientation, then the organization with entrepreneurial characteristics such as innovative, proactive and risk taking (Miller, 1983, 2011 ), will further drive innovation towards driving the market behavior, that tends to encourage innovative business model changes (Schindehutte et al., 2008 ).

From the entire explanation above, this study would essentially excavate the role of entrepreneurial orientation in creating superior and sustainable hospital performance, through business model innovation and collaborative strategic relationship, which in this case is the "hospital - physician relationship" ( HPR ) ( Trybou et al., 2015; Succi et al., 1997 )

The development of firm-level entrepreneurship concept has shown the result since the beginning of the 21 st century because it has gained wider recognition, and is applicable to all types of industry, organization type and age of the company (Nason et al., 2015; Bierwerth et al., 2015). But research in the service sector (including health care delivery services organizations 
as hospitals) has been found in a limited number (Kraus 2011). Research on entrepreneurial orientation in developing countries also has not found to be many in numbers, so it needs a lot of research in order to enhance the implementation and adjustment concept, due to institutional differences (Hughes \& Mustafa, 2016). Past research has shown an inconsistency results of the effect of entrepreneurial orientation on organizational performance (Wales, 2015; Bierwerth et al., 2015). It is still needed a lot of empirical evidence in implementing the concept entrepreneurship within a hospital organization (Rauch, 2015). This paper is written in a systematic order preceded by an introduction, literature review, proposed research model, research methods and conclusion.

\section{Literature Review}

From strategic management perspective, entrepreneurship principles increasingly occupy important position, because both have the same focus which is wealth creation that achieved through the determinants of firm performance (Hitt et al., 2001). The concept of firm level entrepreneurship has been recognized as an integral part of strategic management (Burgelman, 1983; Barringer \& Bluedorn, 1999), especially the concept of entrepreneurial orientation from Miller (1983) used in this study, as the perspective of the most dominant (Rauch et al., 2009) and the most established (Wales, 2015).

\section{Entrepreneurial Orientation}

Entrepreneurial orientation is defined as the attitude of the company in order to pursue new opportunities through a combination of internal resources (Miller, 1983). Entrepreneurial orientation expressed as the process of formation of corporate strategy (Miller, 2011) and is known as a strategic posture of the organization that exhibits innovative attitude, proactive and risk-takers, as a whole or unidimensional (Covin \& Slevin, 1989, 1991; Wales, 2015). The first dimension of entrepreneurial orientation is the innovative attitude which reflects the tendency or propensity of companies to use or establish any new technology or way of working, making it necessary to change from routine jobs that existed before. Companies tend to form creativity and experimentation (Rauch et al., 2009). It can also be the emergence of creative new ideas, new breakthroughs and experimentation process that will encourage the emergence of novelty in technology, products and services (Wiklund \& Shepherd, 2005).

The second dimension is proactive attitude, which is described as anticipatory attitude and the pursuit of new opportunities and respond to the challenges ahead of competitors in the market of the newly formed (Rauch et al., 2009). Proactive is mentioned as the first initiation an attitude of innovation, so that there is an element of speed and act first when viewing opportunities (Miller, 1983). The third dimension is the attitude of risk- takers which is defined as the level of willingness to risk managers or resources committed to putting in a large amount in a risky position, calculable value of the loss in case of failure (Miller \& Friesen, 1982). So we can conclude that entrepreneurial orientation is the orientation of the attitude of the organization towards entrepreneurial activity (Antoncic \& Hisrich, 2003), and reflects the policy, implementation, and the process of formulating a strategy on which to base decision-making and entrepreneurial activity of the organization (Rauch et al., 2009) 


\section{Business Model Innovation}

In facing the threat of disruptive change, innovation is said to be the only solution to meet the challenges of competition, for the salvation of the organization (Kim \& Maubourgne, 2005). It is known that the type of innovation implemented by the entrepreneurial company is an effort of adaptation reaction to the environment by creating new opportunities. For the disruptive change of external environment then the type of innovation needed as an answer for the organization's survival is likely to be revolutionary, rather than evolutionary (Assink, 2006) or with a high level of disruptiveness. That condition requires an innovation which is not only about products or services and methods alone but also about an innovation of the pattern of corporate thinking and new ways to create and capture value for stakeholders with new ways to earn income (Casadesuss-Masanell \& Ricart, 2010 ), which is referred to business model innovation.

Business model innovation is measured by the three-dimensional constituent. The first dimension is the value creation innovation which is defined as the ways and means used by companies to create value throughout the value chain, by utilizing the resources and capabilities within and between organizations process (Clauss, 2015). The second dimension is value proposition innovation, which lists problem solving and how to do deals to clients (Clauss, 2015, Johnson et al., 2008). Finally, the third dimension is value capture innovation which describes how value can be transformed into income (Clauss, 2015).

\section{Strategic Collaboration between Hospital and Physician}

Form of relationship management with the medical profession considered prone to conflicts collaborative relationships that are considered as pressing conflicts and differences. Collaboration reflected by the decision-making process is done together and the result would be a shared responsibility, especially as related to the principles and strategic (Liedtka, 1996; Al Amin et al., 2013). This relationship will also instill the growth of mutual trust (Succi et al., 1998; Trybou et al., 2015). As a result of the dual role of the medical profession within the organization, the medical profession as an asset relational strategic, can be turned into a threat to the survival of the organization in the event of failure of the collaboration, with the strength of its influence on the market ( Al-Amin et al., 2013 ). With the complexity of the forms of integration or relationships hospital with a medical profession that is analogous equivalent to the role of a contractor (Sharma, 1997), and the central role of the medical profession in the operational activities of the hospital, then the ability of hospital manager to maintain the linkage in collaboration with the physician regarded as determinants of hospital competitive advantage (Douglas \& Ryman 2003).

\section{Proposed Research Model and Propositions}

Associated with the dimension of entrepreneurial orientation that support change (innovative and proactive) as well as the tendency in decision making with measurable risk, then it is mentioned that entrepreneurial orientation is a trigger of business model innovation (Bouncken et al., 2016). Entrepreneurial orientation affects business model innovation to prevent the status quo of the organization, due to inertia. This can occur because of the attitude of risktaking, acceptance of the existence of competition and proactive behavior by strengthening 
certain circumstances that is changing regarding the content, structure and governance of the organization's systems activities (Amit \& Zott, 2010).

This explains that the selection of a company's activities, and how it is implemented, showing the interaction between activities and the mechanism for the governance of activities refer to the dynamics rules, can be changed rapidly caused by the firm's entrepreneurial orientation (Chesbrough; 2010; Amit \& Zott, 2010). By encouraging entrepreneurial orientation endogenously, a firm represented experimental attitude and look for potential new business models, before the pressures of external changes are forcing changes in the business model (Chesbrough, 2010).

\section{Proposition 1: The entrepreneurial orientation has a positive influence on business model innovation}

The relationship between the entrepreneurial orientations with firm performance is a major concern to the researchers History (Wales, 2013; Dyduch 2008; George and Marino, 2011). Many studies suggest an inconsistency in relationship between entrepreneurial orientations on performance. There are studies which prove the existance of the direct links (Covin \& Slevin, 1989, 1991; Hinz \& Ingerfurth, 2013). There are researchers who discovered the results of an indirect relationship between entrepreneurial orientations on performance (Walter, 2006, Wales et al., 2013). There was also an inconsistency in result ( Wales et al., 2013). It is assumed that companies with high entrepreneurial orientation tends to achieve better performance than companies that have lower entrepreneurial orientation (Miller \& Friesen, 1982). However, there is another opinion that states that a high level of entrepreneurial orientation is not always, universally, directly providing added value compared to the conservative organization (Wales et al, 2013).

In this study, the hospital with entrepreneurial characteristics assumed to influence the achievement of better performance, because it has properties that enable proactive discover new opportunities earlier than the competition (Vandekerckhove \& Dentchev, 2005). Innovative attitude with proper risk calculation in hospitals tends to push the organization with improved performance, especially with innovative business model, which is opening new markets (Clauss, 2015)

Proposition 2: The entrepreneurial orientation has a positive influence on organizational performance

Using collaboration in fostering the relationship between hospital management and the medical profession is considered to be most appropriate given the relationship is prone to conflict. Collaboration is reflected by the mutual decision-making process and a shared responsibility, especially related to the principles and strategic decisions (Liedtka, 1996; Al Amin et al., 2013). With the complexity of the forms of integration or relationships hospital - physician relation, that is analogous equivalent to the role of the contractor off (Sharma, 1997), and the central role of the medical profession in the operational activities of the services the hospital, then the ability of hospital management to collaborate with the physician isregarded as determinants of the competitive advantage of hospitals (Douglas \& Ryman 2003). Collaboration between 
management and the medical profession assumed to be influenced by the level of entrepreneurial orientation of each hospital. It is argued when the management experienced a proactive and dynamic relationship, it will diminish the risk which can come from the chance of the failure of management to collaborate, according to the nature of the physician position as the "mixed blessing stakeholder" ( Al-Amien et al., 2013)

Measurements of collaboration is reflected by the establishment of trust and togetherness in making decisions and taking responsibility together to bear the risk (Liedtka, 1996 ), regarding investment arrangements, the assignment of physicians, cost efficiency and togetherness in achieving goals (Succi et al, 1998; Trybou et al., 2015). It is argued that with the entrepreneurial orientation, it will form a healthy and strong collaboration in the long term, because it is based on trust and fairness autonomy in decision making on certain strategic fields ( Succi et al., 1998).

Proposition 3: The entrepreneurial orientation has a positive influence on collaboration of hospital - physician relation

Innovation in the organization will require resources and bring uncertainty and the risk of an ignorance (Assink, 2006). Nonetheless, it is expressed as a single solution - only to escape a hyper competition (Kim \& Maubourrgne, 2005). Many studies have concluded that the effect of innovation on the performance depicted varied, inconclusive or contradictory, especially for small and medium-sized firms. Stated that this relationship will depend on the context, such as the age of the company and the type of innovation (Rosenbusch et al., 2011).

In this study, it is argued that in the context of innovation in hospital organization, the more innovations that lead to market expansion and introduction of products services and processes are completely different to the one for this or facilitating access to reach new market segments. Business model innovation created the formation of value which not only improve economic indicators, but also have an impact on social benefits in the form of the legitimacy of the organization of society and government (Hitt et al., 2011). It is argued that business model innovation will open the access of services for a growing number of community members who previously did not constitute service users in the organization (Christensen et al., 2009), so that will improve hospital performance (Bouncken et al., 2016).

\section{Proposition 4: The business model innovation has a positive influence on organizational performance}

The impact of collaborative relationship is said to affect the tendency of the rate of innovation disruptiveness by the organization to achieve the performance (Dobrzikwosky et al., 2015). Their strong collaboration will create a sense of trust among the parties to collaborate and could affect the organization's business model innovation if it is necessary (Rauch, 2015; Christensen et al., 2000). Strong collaboration between parties, within and between organizations, becomes an element of the key resources in the form of partnerships that will affect the innovation value proposition and the arrest of value, which can lead to organizational sustainability (Johnson et al., 2008). With innovation at this stage of value creation in the form of a bond of trust in the collaborative relationship of relational strategic assets, it will directly affect key processes, which form the new income model and a new fee structure as well (Clauss, 2015). 


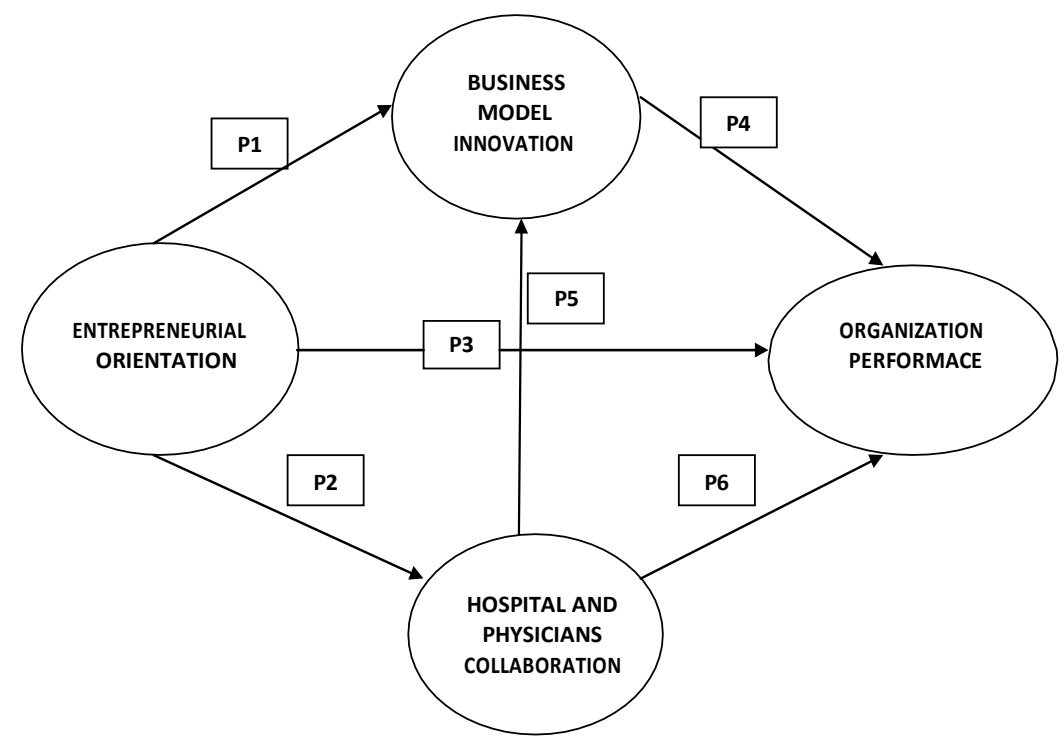

Figure 1. Research Model

Proposition 5: The strategic collaboration of hospital - physician relation has a positive influence on business model innovationn

Collaboration between the management and the medical profession is a unique stakeholder dyadic relationship (Al Amien et al., 2013), and said to be strategic resources because it affects organizational performance directly (Amit \& Schoemaker, 1993; Barney, 1991). This collaboration is an asset that influences market demand because it is formed through a process of engagement (Srivastava et al., 1998). Collaboration as mediation between entrepreneurial orientations on performance has not been found, although the success of the hospital is strongly associated with management collaboration with physicians (Douglas \& Ryman 2003; Trybou et al., 2015; Al Amien et al., 2013)

The collaboration will vary and are unique in comparable between organizations as it will depend on the elements of the policy owner respective organizations and through resource orchestration will have a positive effect on the achievement of organizational performance (Wales et al., 2013; Walter, 2006). Measurement of collaborative relationships between hospital and the physician in this study is based on two factors: the determining factors of trust and the balance factor of power or influence by management and clinicians in decision making regarding investment arrangements, the assignment of physicians, cost efficiency and togetherness in achieving goals (Succi et al, 1998; Trybou et al., 2015). Then argued that with the healthy collaboration, it will be a positive influence on the achievement of organizational performance hospital.

Proposition 6: The collaboration of hospital - physician relation has a positive influence on organizational performance

Based on the above explanation, proposed research model as Figure 1. 


\section{7. $\quad$ Research Method}

This conceptual paper builds on the idea of how Indonesian hospitals can maintain their best performance under uncertain environmental conditions such as today. So it is argued that the strategic orientation of the firm that reflects as an entrepreneurial organization will be very appropriate to overcome the challenges of disruptive change. Based on the rationale mentioned above, then constructed the propositions about how entrepreneurial orientation can affect performance, especially through proactive and innovative dimensions that always encourage change. It turns out that with the encouragement of these changes, it will strengthen the innovation of business models and strategic collaboration between management and the physicians who will eventually create organizational performance.

For its continuation, empirical research still needs to be done to test the model by using the quantitative method. The next study will be conducted by using private hospitals as unit analysis, located in Jakarta and surrounding areas. The data which will be obtained is the perception of top managers and mid-level of the entire process associated with the condition, activities and processes related to entrepreneurial orientation, which is the strategic position of the hospital organization. This is related to the strategic role of top and middle management in the hospital organizations, which will determine the firm's strategic posture that exhibit a proactive, innovative and risk-taker with a full calculation behavior (Ireland et al, 2009 ).

\section{Conclusion}

Implementation of entrepreneurial orientation in hospital organization, is relatively new in health care industry in Indonesia. Amid environmental uncertainty triggered by regulatory changes and digital disruption in the hospital environment, this conceptual paper is expected to create an insight for all stakeholders, to re-think the appropriate hospital business model to addressing the challenge of disruptive change. From the literature review in this paper, it is argued that hospital performance will be influenced by the entrepreneurial orientation, either directly or through the mediation of business model innovation and strategic collaboration between hospital management and the physicians. As for the theoretical contribution, this study can enrich the development of entrepreneurial orientation concept as a part of organizational entrepreneurship which emphasizes the relationship of the stakeholders of an industry.

\section{References}

Al-Amin, M., Weech-Maldonado, R., \& Pradhan, R. (2013 ) Hospital - physician relationships: Implication for professional service firms literature. Advances in Health Care Management, 15, 165-184

Amit, R., \& Zott, C. ( 2010 ) Business model innovation: Creating value in times of change. Working paper- IESE Business Scholl, University of Navera, 1-15 
Amit, R., Schoemaker, P. J. H. ( 1993) Strategic assets and organizational rent. Strategic Management Journal, 14, 33-46

Antoncic, B., Hisrich, R. D.(2003 ) Clarifying the intrapreneurship concept. Journal of small business and entreprise development, 10(1), 7-24.

Assink, M. ( 2006 ) Inhibitors of disruptive innovation capability. European Journal of Innovation Management, 9(2), 215-233

Barney, J. B. ( 1991 ). Firm resources and sustained competitive advantage. Journal of Management. 17(1), 99-120

Barringer, B.R., \& Bluedorn, A. C. ( 1999 ) The relationship between corporate entrepreneurship and strategic management. Strategic Management Journal, 20(5), $421-444$

Bierwerth, M., Schwens, C., Isidor, R., \& Kabst, R. ( 2015 ) Corporate entrepreneurial and performance: A meta analysis. Small Business Economics, 45(2), 255-278

Bouncken, R.B., Lehman, C., \& Fellnhofer, K ( 2016 ) The role of entrepreneurial orientation and modularity for business model innovation in service company. International Journal Entrepreneurial Venturing, 8(3) 237-260.

Casadesus-Masanell, R., \& Ricart, J. E. ( 2010 ) From strategy to business models on to tactics. Long Range Planning. 43, 195-215.

Chen, M. J., Miller, D. ( 2015 ) Reconceptualizaing competitive dynamics: A multidimensional framework. Strategic Management Journal, 36, 758-775.

Chesbrough, H. ( 2010 ) Business Model Innovation: Opportunity and barriers. Long Range Planning, 43, 354-363.

Christensen, C. M., \& Overdorf, M. (2000) 'Meeting the challenge of disruptive change', Harvard Business Review, 78, 2, 66-77.

Christensen, C. M., Grossman, J. H. and Hwang, J. (2009) The innovator's prescription: A disruptive solution for health care, New York: McGraw-Hill.

Christensen, C.M. \& Raynor, M ( 2003 ) The innovator's solution : Creating and sustaining successful growth. Boston, MA : Harvard Business School Press.

Christensen, C.M., Raynor, M., \& McDonald R. ( 2015 ) What is disruptive innovation? Harvard Business Review, December, 1-11

Clauss, T. ( 2015 ) Measuring Business Model Innovation: Conceptualization, scale development and proof of performance. $R \quad \& \quad D$ Management, doi:10.1111/radm.12186, 1-31 
Covin, J.G. ( 1991 ) Entrepreneurial versus conservative firms: A comparative of strategies and performance. Journal of Management Studies, 28(5), 439-462.

Covin, J.G., \& Lumpkin, G. T. (2011) Entrepreneurial orientation theory and research: Reflections on a needed construct. Entrepreneurship: Theory \& Practice 35(5): 855872.

Covin, J.G.,\& Slevin, D.P. ( 1989 )Strategic management on small firm and benign environment. Strategic Management Journal, 10, 75-87

Covin., J.G., \& Slevin, D.P. ( 1991 ) A conceptual model of entrepreneurialas a firm behavior. Entrepreneurial Theory and Practice, 14(4 ), 35-50

Dobrzykowsky, D.D., Callaway, S.K., \& Vonderembse, M. A. ( 2015 ) Examining pathways from innovation orientation to patient satisfaction. Decision Sciences, 46(5), 863-899

Douglas, T.J., \& Ryman., J.A. ( 2003 ) Understanding competitive advantage in general hospital industry: evaluating strategic competencies. Strategic Management Journal, 24, 333-347

Guo, K.L. ( 2006 ) Entrepreneurial management in health services : An integrative model. Journal of Health and Human Services Adminitration, 28 (3/4 ), 504-531.

Hitt, M. A., Ireland, R. D., Camp, M., \& Sexton, D. L. ( 2001 ) Guest Editors' introduction to special issue strategic entrepreneurship: Entrepreneurial strategies for wealth creation. Strategic Management Journal, 22, 479-491.

Hwang, J. \& Christensen, C.M. ( 2008 ) Disruptive innovation in health care delivery: A framework for business model innovation. Health Affairs, 27(5), 1329-1335..

Ireland, R.D., Kuratko, D. F., \& Covin, J. G ( 2003 ) Antecedents, elements and consequences of corporate entrepreneurship strategy. Academy of Management Best Converence Paper, L1 - L6.

Johnson, M. W., Christensen, C. M., \& Kagermann, H. ( 2008 ): Reinventing your business model. Harvard Business review, Desember, 58-67.

Jung, C. \& Padman, R ( 2015 ) Disruptive digital innovation in healthcare delivery: The case for patient portals and online clinical consultations. In Agarwal, et al (Eds), The handbook of service innovation. London : Springer - Verlag.

Kaissi, A. ( 2012 ) Learning from other industries- Lessons and challenges for health care organizations. The Health Care Manager, 31(1), 65-74.

Kim, W.C., \& Maubourgne, R. ( 2005 ) Blue ocean strategy : from theory to practice. California Management review, 47(3), 105-121 
Kraus, S. ( 2011) The role of entrepreneurial orientation in service firms: empirical evidence in Austria. The Service Industries Journal, First Article, 1-18

Kuratko, D.F. ( 2009 ) The entrepreneurial imperative of the 21st century. Business Horizons, 52(5), $421-428$.

Kuratko, D.F., Hornsby, J.S., \& Hayton, J. ( 2015 ) Corporate entrepreneurship : the innovative challenge for a new global economic reality. Small Business Economics, 45(2), 245253.

Liedtka, J.M. ( 1996 ) Collaborating across lines of business for competitive advantage. Academy of Management Executive, 10(2), 20-34

Maier, F., Meyer, M., \& Steinbereithner, M. ( 2014 ) Non profit organizations becoming business-like : A Systematic Review. Nonprofit and Voluntary Sector Quarterly, October, 1-23.

Miller D and Friesen P.H. (1982) Innovation in conservative and entrepreneurial firms: Two models of strategic momentum. Strategic Management Journal 3(1), 1-25.

Miller D and Friesen P.H. (1983) Strategy- making environment: The third link. Strategic Management Journal 4(3), 221-235

Miller, D. (2011) Miller (1983) revisited: A reflection on EO research and some suggestions for the future. Entrepreneurship: Theory \& Practice 35(5), 873-894.

Miller, D.( 1983 ) The correlates of entrepreneurial in three types of firms, Management Science, 26, 770-791.

Nason, R..S., McKelvie, A.,\& Lumpkin, G.T. ( 2015 ) The role of organizational size in heterogeneous nature of corporate entrepreneurship. Small Business Economics, 45(2), 279-304.

Porter, M. E \& Teisberg, E.O. ( 2004 ) Redefining competition in health care. Harvard Business Review, June, 65-76.

Porter,M. E., \& Lee, T. H. ( 2013 ) The strategy that will fix healthcare. Harvard Business Review, October, 1-19.

Rauch A, Wiklund .J., Lumpkin G.T., \& Frese, M. (2009) Entrepreneurial orientation and business performance: An assessment of past research and suggestions for the future. Entrepreneurship: Theory \& Practice 33(3), 761-787

Rauch, J. ( 2015 ) Disruptive entrepreneurship is transforming U.S. health care. Center of Effective Public Management, March, 1-19.

Rosenbusch, N., Rauch, A., \& Bausch, A. ( 2011 ) The mediating role of entrepreneurial orientation in the task environment - Performance relationship: A meta - analysis. Journal of Management, 39(3), 633-659. 
Schindehutte, M, Morris, M.H., \& Kocak, A. ( 2008 ) Understanding market-driving behavior: The role of entrepreneurship. Journal of Small Business Management, 46(1), 4-26.

Su, Z. Xie,, E., Wang, D., \& Li, Y. ( 2011 ). Entrepreneurial strategy making, resources, and firm performance : Evidence form China. Small Business Economics, 36, 235-247

Succi, M.J., Lee, S.Y., \& Alexander, J.A. ( 1998 ) Trust between managers and physician in community hospitals: The effects of power over hospital decisions. Journal of Healthcare Management, 43(5), 397-414

Trybou, J., De Caluwe, G., Verleye, K., Gemmel, B., \& Annemans, L. (2015 ) The impact of professional and organizational identification on the relationships between hospital-physician exchange and customer-oriented behavior of physicians. Human Resources for Health, 13(8), 1-9

Vandekerckhove, W., \& Dentchev, N. A. ( 2005 ) A network perspective on takeholder management : Facilitating entrepreneurs in the discovery of opportunity. Journal of Business Ethics, 60, 221-232.

Wales, W. J. ( 2015 ) Entrepreneural orientation : A review and synthesis of promising research direction. International Small Business Journal, 34(1), 3-15

Wales, W. J., Patel, P.C., Parida, P., \& Kreiser, P.M. ( 2013 ) Non linear effects of entrepreneurial orientation on small firm performance: The moderating role of resource orchestration capabilities. Strategic Entrepreneurial. Journal, 7, 93-121.

Wiklund, J., \& Shepherd, D. (2005), Entrepreneurial Orientation and Small Business Performance: a Configurational Approach, Journal of Business Venturing, 20, 71-91. 